\title{
RELASI NEGARA DAN PASAR BEBAS \\ DALAM MEWUJUDKAN KEADILAN EKONOMI: Analisis Sejarah Keuangan Publik Islam
}

\author{
Aan Jaelani \\ Fakultas Syari'ah dan Ekonomi Islam \\ Institut Agama Islam Negeri Syekh Nurjati Cirebon \\ e-mail: iainanjal@gmail.com
}

\begin{abstract}
The state becomes a political entity that is responsible for the collective affairs of the community so that it plays an important role in creating economic justice and prospering the community through instruments of development. However, the role of the government in carrying out development depends on public finance which in fact has problems in terms of management and implementation. In the perspective of Islamic economics, public finance is a top priority managed from the side of the sources of income and expenditure used in implementing pro-poor development so as to create prosperity for the community.
\end{abstract}

Keywords: Ushuliyah Rules, Fiqhiyyah Rules, Furuiyyah Rules and Islamic Economics.

\begin{abstract}
Abstrak
Negara menjadi entitas politik yang bertanggung jawab terhadap urusan kolektif masyarakat sehingga berperan penting dalam menciptakan keadilan ekonomi dan mensejahterahkan masyarakat melalui instrumen pembangunan. Meski demikian, peranan pemerintah dalam melaksanakan pembangunan bergantung pada keuangan publik yang secara faktual memiliki masalah dari sisi pengelolaan dan implementasinya. Dalam perspektif ekonomi Islam, keuangan negara menjadi prioritas utama yang dikelola dari sisi sumber-sumber pendapatan dan pengeluaran yang digunakan dalam melaksanakan pembangunan yang pro-poor sehingga menciptakan kesejahteraan bagi masyarakat.
\end{abstract}

Kata Kunci: State, Free-Market, Economy Justice and Public Finance. 


\section{PENDAHULUAN}

Dalam Islam, pasar dijamin kebebasannya dalam menentukan cara-cara produksi dan harga, tidak boleh ada gangguan yang mengakibatkan rusaknya keseimbangan pasar. Namun dalam kenyataannya sulit ditemukan pasar yang berjalan sendiri secara adil (fair). Distorasi pasar tetap sering terjadi, sehingga dapat merugikan para pihak. Pasar yang dibiarkan berjalan sendiri (laissez faire), tanpa ada yang mengontrol, ternyata telah menyebabkan penguasaan pasar sepihak oleh pemilik modal (capitalist) penguasa infrastruktur dan pemilik informasi. Asymetrik informasi juga menjadi permasalahan yang tidak bisa diselesaikan oleh pasar. Pemerintah mempunyai peran yang sama dengan pasar, tugasnya adalah mengatur dan mengawasi ekonomi, memastikan kompetisi di pasar berlangsung dengan sempurna, informasi yang merata dan keadilan ekonomi. ${ }^{1}$ Perannya sebagai pengatur tidak lantas menjadikannya dominan, sebab negara, sekali-kali tidak boleh mengganggu pasar yang berjalan seimbang, perannya hanya diperlukan ketika terjadi distorsi dalam sistem pasar.

Sri-Edi Swasono ${ }^{2}$ menjelaskan bahwa tidak ada yang dapat mengabaikan peranan pasar. Kita pun memelihara ekonomi pasar. Yang kita tolak adalah pasar-bebas. Pasar-bebas adalah imaginer, yang hanya ada dalam buku teks, berdasar asumsi berlaku sepenuhnya persaingan bebas. Dalam realitas, tidak ada persaingan bebas sepenuhnya, kepentingan nonekonomi, khususnya kepentingan politik

\footnotetext{
${ }^{1}$ Ziauddin Ahmed, etc., Fiscal Policy and Resource Allocation in Islam (Jeddah: King Abdul Aziz University \& Islamabad: Institute of Policy Studies, 1996), 28. Baca pula Sabahuddin Azmi, Islamic Economics: Public Finance in Early Islamic Thought (New Delhi: Goodword Books, 2002), 3437.

${ }^{2}$ Sri-Edi Swasono, Ekspose Ekonomika: Mewaspadai Globalisasi dan Pasar Bebas (Yogyakarta: Pustep-UGM, 2010), 83-90 dan 137148.
}

(lokal atau global), telah mendistorsi dan menghalangi terjadinya persaingan bebas (embargo, economic sanctions, disguised protections, strict patents and copy rights, dll). Tanpa persaingan bebas, sebagaimana dalam kenyataannya, tidak akan ada pasarbebas yang sebenarnya. Maka Adam Smith boleh terperanjat bahwa the invisible hand has turned into a dirty hand.

Pasar-bebas menjadi penyebab sikap diskriminatif terhadap yang rendah produktivitasnya (tidak efisien), akibatnya tidak mudah memperoleh alokasi kredit yang berdasar profitability itu. Pasar-bebas jelas melintangi hak demokrasi ekonomi rakyat, yang miskin tanpa daya beli akan hanya menjadi penonton belaka, berada di luar pagar-pagar transaksi ekonomi. Pasarbebas melahirkan privatisasi yang melepaskan cabang-cabang produksi yang penting bagi negara dan yang menguasai hajat hidup orang banyak ke tangan individu-individu. Pasar-bebas mencari keuntungan ekonomi bagi orang-seorang, bukan manfaat ekonomi bagi masyarakat. ${ }^{3}$

Perekonomian Indonesia tentu tidak dapat melepaskan diri dari pengaruh kondisi perekonomian dunia. ${ }^{4}$ Pada tahun 2019, perekonomian dunia diproyeksi akan lebih baik dibandingkan dengan kondisi tahun 2018 terutama akan didorong oleh perekonomian di negara maju. Berbagai kebijakan dan stimulus ekonomi yang telah dilakukan selama ini telah berhasil mengurangi kerentanan perekonomian di negara maju. Meskipun demikian, pada tahun 2019, perekonomian global diperkirakan akan menghadapi beberapa tantangan antara lain yaitu rencana kenaikan suku bunga di Amerika Serikat yang berpotensi memberikan gejolak pada pasar

${ }^{3}$ Sri-Edi Swasono, Indonesia dan Doktrin Kesejahteraan: Dari Klasikal dan Neoklasikal sampai ke The End of Laissez-Faire (Jakarta: Perkumpulan Prakarsa, 2010), 48-64.

${ }^{4}$ Aan Jaelani, Fiscal Policy in Indonesia: Analysis of State Budget 2017 in Islamic Economic Perspective. International Journal of Economics and Financial Issues, 2017: 7 (5): 14-24. 
keuangan dan perlambatan kinerja perekonomian di Tiongkok. Kedua faktor tersebut diperkirakan akan mempengaruhi akselerasi pertumbuhan ekonomi di negaranegara berkembang termasuk Indonesia. Dari sisi domestik, stabilitas ekonomi makro yang terjaga dengan baik serta terpilihnya pemerintahan yang baru secara demokrasi merupakan faktor pendorong akselerasi perekonomian nasional.

Gambaran perekonomian Indonesia di atas menunjukkan bahwa negara merupakan entitas politik yang bertanggung jawab terhadap urusan kolektif masyarakat, bukan hanya terkait dengan urusan duniawi melainkan juga ukhrawi. Dalam pandangan Monzer Kahf, 5 persoalan keuangan publik yang mencakup pendapatan publik dan pembelanjaan publik memiliki dua kriteria, yaitu untuk melayani dengan baik kepentingan-kepentingan seluruh anggota komunitas bangsa, dan mengatur kepentingan tersebut berdasarkan sumbersumber kewahyuan. Oleh karena itu, tulisan ini akan menjelaskan tentang bagaimana relasi negara dan pasar bebas dalam mewujudkan keadilan ekonomi?

\section{LITERATURE REVIEW}

Penelitian tentang relasi negara dan pasar bebas dalam mewujudkan keadilan ekonomi bukanlah suatu yang baru. Meskipun demikian, nampaknya belum ditemukan penelitian yang secara spesifik menganalisis penelitian di atas melalui sejarah keuangan publik Islam. Berikut beberapa karya yang terdokumentasikan terkait permasalahan yang dikaji, yaitu pertama, Metin $\mathrm{M}$. Cosgel $^{6}$ dalam "Efficiency and Continuity in Public Finance: The Ottoman System of

${ }^{5}$ Monzer Kahf,"Public Finance and Fiscal Policy in Islam", dalam Monzer Kahf (ed.), Lessons in Islamic Economic (Jeddah: IDB-IRTI, 1998), 455.

${ }^{6}$ Mengenai sejarah praktek keuangan publik pada masa Utsmani ini dapat dibaca Metin $M$. Coşgel,'Efficiency and Continuity in Public Finance: The Ottoman System of Taxation," International Journal of Middle East Studies 37(4) (2005), 567586.
Taxation". Menurut Cosgel bahwa pasca keruntuhan Baghdad, salah satu Dawlah yang menjadi kekuatan politik Islam adalah Turki Utsmani, di samping dinasti MughalIndia dan Safawi-Persia. Praktek keuangan publik berkembang pula pada masa ini seiring dengan perluasan wilayah Islam sampai Eropa dengan menyerap organisasi pemerintahan dan kemiliteran alaBizantium.

Dan kedua, Mohamad Sabri Haron ${ }^{7}$ dalam "Wealth Protection in The Context of Maqasid Syariah: Malaysia's Role ini Realizing The Concept of Economic Jihad". Melalui penelitiannya, Haron menyatakan bahwa Maqasid Syariah tentang harta menjadi wasilah yang penting untuk mencapai objektif yang paling tinggi yaitu perlindungan terhadap agama (Hifdzu adDin). Untuk merealisasikan hal ini, Malaysia telah meletakkan ekonomi sebagai suatu jihad penting untuk mencapai kesejahteraan dalam kehidupan. Penelitian ini ini menjelaskan konsep perlindungan terhadap harta menurut Islam dalam konteks maqasid syariah dan bagaimana peranan Malaysia untuk mengaplikasinya khususnya kepada masyarakat Islam dilanjutkan institusi-institusi keuangan Islam yang berpotensi di Malaysia menerusi pendekatan jihad ekonomi.

Dalam penelitian terdahulu di atas, hanya mendeskripsikan sejarah praktek keuangan publik dan berpusat pandangan maqasid dalam aspek lain, tanpa menggambarkan penjelasan permasalahan yang ada. Hal ini berbeda dengan penelitian ini yang mencoba untuk mengungkapkan relasi negara dan pasar bebas dalam mewujudkan keadilan ekonomi dengan analisis sejarah keuangan publik Islam.

\footnotetext{
${ }^{7}$ Mohamad Sabri Haron, "Wealth Protection in The Context of Maqasid Syariah: Malaysia's Role ini Realizing The Concept of Economic Jihad", Jurnal Hadhari Edisi Khas 2:2 (Desember 2017): 144.
} 


\section{METODOLOGI PENELITIAN}

Jenis penelitian yang digunakan adalah penelitian kepustakaan, merupakan penelitian yang penemuanya didapatkan dengan mencari data dari berbagai literatur dan referensi yang berhubungan dengan materi pembahasan. ${ }^{8}$ Selain itu, penelitian kepustakaan di sini akan dipadukan dengan analisis sejarah keuangan publik Islam. Hal ini penting, karena akan mengungkap relasi negara dan pasar bebas dalam mewujudkan keadilan ekonomi. Negara memiliki peran utama dalam mengelola keuangan yang digunakan untuk mewujudkan keadilan ekonomi. Keuangan negara atau keuangan publik menjadi bagian utama dalam penyelenggaraan pembangunan ${ }^{9}$ yang seyogyanya bertujuan untuk mewujudkan keadilan ekonomi dan kesejahteraan masyarakat di tengah arus pasar bebas.

Kemudian, penelitian ini juga menggunakan pendekatan kualitatif normatif, yaitu sebagaimana cara yang digunakan dalam penelitian hukum yang dilakukan dengan cara meneliti bahan pustaka yang ada. ${ }^{10}$

Teknik pengumpulan data merupakan langkah yang paling strategis dalam penelitian, karena tujuan utama dari penelitian adalah mendapatkan data. ${ }^{11}$ Peneliti melakukan teknik pengumpulan data dengan melakukan penelitian terhadap berbagai literatur yang dilakukan untuk

\footnotetext{
${ }^{8}$ Moh. Nazir, Metode Penelitian (Bandung: Ghalia Indonesia, 2003), 93.

${ }^{9}$ Al-Mawardi, al-Ahkam as-Sulthaniyah waal-Wilayat ad-Diniyah (Beirut: Dar al-Fikr, 2005), 185. Menurut Abu Ubayd, tanah ini digunakan untuk kuda-kuda yang dipakai dalam peperangan. Abu Ubayd, Kitab al-Amwal (Cairo: Maktabah alTijariyah al-Kubra, 1934), 185. Lihat juga Aan Jaelani, Masyarakat Islam dalam Pandangan alMawardi (Bandung: Pustaka Setia, 2006).

${ }^{10}$ Soerjono Soekanto dan Sri Mamudji, Penelitian Hukum Normatif Suatu Tinjauan Singkat, Cet. 11 (Jakarta: PT. Raja Grafindo Persada, 2009), 13-14.

${ }^{11}$ Sugiyono, Metode Penelitian Kuantitatif Kualitatif Dan R \& D (Bandung: Alfabeta, 2013), 224.
}

mencari konsep yang ada relevansinya dengan topik pembahasan melalui pengkajian buku-buku, jurnal, majalah, serta pendapat para ahli secara tidak langsung, yang kemudian akan dianalisis secara mendalam. Selain itu, penelitian ini menggunakan teknis analisis deskriptif, yaitu analisis dengan cara memaparkan data yang telah terkumpul dan tersusun secara sistematis. ${ }^{12}$

Sumber diperoleh dari dokumen dan informasi beberapa temuan-temuan di berbagai jurnal dan hasil penelitian sebelumnya. Dokumen tersebut telah melalui tahapan-tahapan analisis dari berbagai keabsahan data atau sumber yang banyak dikaji oleh para peneliti, serta dianalisis tentang relasi negara dan pasar bebas dalam mewujudkan keadilan ekonomi.

\section{KONSEP DASAR \\ Pasar Bebas dan Keadilan Ekonomi}

Peran negara semestinya terimplementasi dalam bentuk transformasi misi kenabian, ${ }^{13}$ yang dalam konteks Indonesia berdasarkan nilai-nilai Pancasila. Misi kenabian berupa implementasi ajaran agar pemerintah dapat melaksanakan peran dan fungsinya dalam membangun masyarakat yang sejahtera. Nilai-nilai Pancasila mengajarkan bahwa pembangunan nasional diselenggarakan untuk menciptakan keadilan sosial bagi seluruh rakyat Indonesia. Jika diintegraikan dengan gagasan al-Syatibi, pembangunan ekonomi seyogyanya diarahkan untuk mencapai al-maqashid asy-syari' 'ah (tujuantujuan syari'ah). ${ }^{14}$

Konsep al-maqashid asy-syari 'ah ini menegaskan bahwa pembangunan semestinya mengarahkan pada kehidupan keagamaan yang harmonis di Indonesia

\footnotetext{
${ }^{12}$ Jalaludin Rahmat, Metodologi Hukum (Jakarta: Fajar Agung, 1997), 134.

${ }^{13}$ Lebih lanjut baca Al-Mawardi, Adab adDunya wa-ad-Din (Beirut: Dar al-Fikr, 1995), 94.

${ }^{14} \mathrm{Abu}$ Ishaq al-Syatibi, al-Muwafaqat $f i$ Ushul asy-Syari'ah (Cairo: al-Maktabah al-Tijaniyah al-Kubra, 1975), II/6-7.
} 
sebagai refleksi dari hifz al-din, memberdayakan manusia secara mandiri yang mampu memenuhi kebutuhan hidup sebagai implementasi dari hifz al-nafs, meningkatnya sumber daya manusia yang beriman, cerdas, dan terampil sebagai refleksi dari hifz al-'aql, meningkatnya kesejahteraan keluarga dengan adanya peluang kerja yang baik dan distribusi pendapatan yang merata sebagai refleksi dari hifz al-nasl, dan meningkatnya pendapatan individu secara finansial dan kemauan untuk mendistribusikannya dengan membagi kepada orang yang membutuhkan sebagai refleksi dari hifz al-mal.

Dalam ekonomi Islam, meskipun pasar itu bersifat bebas, tetapi ada normanorma penting yang menjadi kerangka dan landasan bagi para pelaku pasar. Suatu kebebasan dengan nilai-nilai keadilan yang semestinya ada dalam pasar. Moralitas pelaku pasar pun sangat penting dalam menciptakan stabilitas ekonomi, sehingga secara tegas Islam melarang segala bentuk penyimpangan dan tindakan ekonomi yang tidak sesuai dengan maqashid syari'ah, seperti penipuan, ihtikar, riba, dan sebagainya. Namun, tetap saja kondisi sekarang ini sangat sulit untuk menciptakan suatu keadilan pasar, sehingga pasar bebas merupakan imaginer.

Hubungannya dengan mekanisme pasar, Abu Yusuf, yang hidup di awal abad kedua Hijriyah (731-798 M) telah membahas tentang hukum supply and demand dalam perekonomian. Menurut Abu Yusuf, bila tersedia sedikit barang, maka harga akan mahal dan bila tersedia banyak barang, maka harga akan murah. ${ }^{15}$

Dalam mekanisme pasar, tingkat harga tidak hanya bergantung pada penawaran semata, namun kekuatan permintaan juga penting. Oleh karena itu kenaikan atau penurunan tingkat harga tidak selalu harus berhubungan dengan kenaikan dan penurunan produksi saja.

\footnotetext{
${ }^{15} \mathrm{Abu}$ Yusuf, Kitab al-Kharaj (Kairo: Maktabah al-Salafiyah, 1970), 80.
}

Pandangan Ibnu Taymiyah tentang mekanisme pasar melalui analisis teori harga dan kekuatan supply and demand cukup penting dalam memahami politik ekonomi negara. Masyarakat saat itu beranggapan bahwa kenaikan harga merupakan akibat dari ketidakadilan dan tindakan melanggar hukum dari si penjual, atau mungkin sebagai akibat manipulasi pasar. Namun, menurut Ibnu Taymiyah, harga ditentukan oleh kekuatan penawaran dan permintaan (supply and demand). ${ }^{16}$

Di dalam sebuah pasar bebas, harga dipengaruhi dan dipertimbangkan oleh kekuatan penawaran dan permintaan (supply and demand). Suatu barang akan turun harganya bila terjadi keterlimpahan dalam produksi atau adanya penurunan impor atas barang-barang yang dibutuhkan. Dan sebaiknya ia mengungkapkan bahwa suatu harga bisa naik karena adanya "penurunan jumlah barang yang tersedia" atau adanya "peningkatan jumlah penduduk" mengindikasikan terjadinya peningkatan permintaan.

Berbagai persoalan dapat muncul pula akibat pasar bebas karena kemungkinan untuk mewujudkan harapan tersebut adalah sangat sulit atau bahkan tidak mungkin terwujud. Umar Chapra ${ }^{17}$ memberikan alasan bahwa ada beberapa distorsi dalam mengekspresikan prioritas di dalam pasar. Hal ini menyebabkan terjadinya bias dalam merealisasikan efisiensi dan keadilan. Munculnya distorsi dalam mengekspresikan prioritas dalam sistem pasar diakibatkan ketidaksukaan ekonomi konvensional pada penilaian normatif dan tekanannya yang berlebihan pada maksimalisasi kekayaan, memuaskan keinginan serta melayani kebutuhan pribadi jelas merupakan penyimpangan

${ }^{16}$ Ibn Taymiyah, al-Hisbah fi al-Islam, (Beirut: Dar al-Kutub al-'Arabiyah, 1990), 2; dan Abdul Azim Islahi, Economic Concepts of Ibnu Taimiyah (United Kingdom: The Islamic Foundation, 1996), 179-180.

${ }^{17}$ Umar Chapra, The Future of Economics: An Islamic Perspective (SEBI: 2001), 38. 
falsafah dasar dari sebagian besar agama. Agama-agama ini secara umum yakin bahwa kesejahteraan material, meski penting, tidak cukup bagi kesejahteraan manusia.

Namun demikian, Ibnu Taymiyah menentang adanya intervensi pemerintah dengan peraturan yang berlebihan saat kekuatan pasar secara bebas bekerja untuk menentukan harga yang kompetitif. Dengan tetap memperhatikan pasar tidak sempurna, ia merekomendasikan bahwa bila penjual melakukan penimbunan dan menjual pada harga yang lebih tinggi dibandingkan harga modal, padahal orang membutuhkan barang itu, maka penjual diharuskan menjualnya pada tingkat harga ekuivalen.

Dalam pandangan al-Ghazali, ${ }^{18}$ peranan aktivitas perdagangan dan timbulnya pasar yang harganya bergerak sesuai dengan kekuatan penawaran dan permintaan. Pasar merupakan bagian dari keteraturan alami. Pandangan lainnya tentang elastisitas permintaan, yaitu mengurangi margin keuntungan dengan menjual pada harga yang lebih murah akan meningkatkan volume penjualan dan ini pada gilirannya akan meningkatkan keuntungan. ${ }^{19}$

Secara jelas, Sri-Edi Swasono ${ }^{20}$ menegaskan pula bahwa pasar-bebas menggeser dan bahkan menggusur rakyat dari tanah dan usaha-usaha ekonominya. Pasar-bebas, yang terbukti tidak omniscient dan omnipotent mampu mengatasi bahkan memperkukuh ketimpangan struktural, lantas mendorong terbentuknya polarisasi sosial-ekonomi, memperenggang integrasi sosial dan persatuan nasional. Pasar-bebas memelihara sistem ekonomi subordinasi yang eksploitatif, non-partisipatif dan nonemansipatif, atas kerugian yang lemah. Pasar-bebas mereduksi manusia sebagai

\footnotetext{
${ }^{18}$ Al-Ghazali, Ihya' 'Ulum ad-Din (Beirut: Dar al-Nadwah, 1995), II/135.

${ }^{19}$ Al-Ghazali, Ihya' 'Ulum ad-Din, II/135168.

${ }^{20}$ Sri-Edi Swasono, Kebersamaan dan Asas Kekeluargaan: Mutualism \& Brotherhood (Jakarta: UNJ Press, 2005), 189-212.
}

sumber daya insani menjadi sumber daya manusia atau faktor produksi ekonomi belaka. Dengan pasar-bebas maka people empowerment kelewat sering berubah menjadi people disempowerment.

Karena itu, al-Ghazali mengemukakan teori tentang profit dalam Islam. $^{21}$ Menurutnya, motif berdagang adalah mencari keuntungan. Tetapi ia tidak setuju dengan keuntungan yang besar sebagai motif berdagang, sebagaimana yang diajarkan kapitalisme. Keuntungan bisnis yang ingin dicapai seorang pedagang adalah keuntungan dunia akhirat, bukan keuntungan dunia saja; yaitu: pertama, harga yang dipatok si penjual tidak boleh berlipat ganda dari modal, sehingga memberatkan konsumen, kedua, berdagang adalah bagian dari realisasi ta'awun (tolong menolong) yang dianjurkan Islam. Pedagang mendapat untung sedangkan konsumen mendapatkan kebutuhan yang dihajatkannya, dan ketiga, berdagang dengan mematuhi etika ekonomi Islami, merupakan aplikasi syari`ah, maka ia dinilai sebagai ibadah.

Persoalan lain terkait adanya sikap berlebihan dalam memposisikan pasar bebas. Sri-Edi Swasono $^{22}$ menjelaskan bahwa pemujaan dan penyandaran (reliance) pada pasar-bebas merupakan ujud dan parsialitas pemikiran ekonomi (mainstream) yang hanya mampu mengakui persaingan (competition) dan inisiatif individual sebagai penggerak kemajuan ekonomi global, mengabaikan kerjasama (cooperation) sebagai penggerak kekuatan ekonomi berdasar mutualitas antar individu yang tak kalah handalnya.

145.

${ }^{21}$ Al-Ghazali, Ihya' 'Ulum ad-Din, II/137-

${ }^{22}$ Sri-Edi Swasono, Ekspose Ekonomika: Mewaspadai Globalisasi dan Pasar Bebas (Yogyakarta: Pustep-UGM, 2010), 83-90. 
PEMBAHASAN DAN DISKUSI

\section{Peran Negara dalam Pengelolaan Keuangan Publik}

Komunitas Muslim di Mekkah pada periode Islam awal ${ }^{23}$ tidak memiliki entitas politik, melainkan bagian dari penduduk Mekkah. Kemudian setelah beberapa orang memeluk agama baru (Islam) dan mereka menerima penganiayaan, Nabi Muhammad SAW. mulai mencari suatu tempat atau tanah baru agar Islam dapat berkembang secara bebas, para pemeluknya dapat menjalankan syari'ah, dan tentunya mereka terbebas dari berbagai bentuk penyiksaan. Nabi beserta pengikutnya mencari tempat yang aman sampai ke Ethopia dan berpikir mengenai tempat-tempat di Arabia, sampai akhirnya melakukan migrasi (hijrah) ke Yatsrib (Madinah).

Hijrah ke Madinah menjadi peristiwa penting karena menandai awal permulaan pemerintahan dan kemunculan masyarakat berdasarkan wahyu ketuhanan (divine revelation). Di Madinah, Nabi meletakkan dasal-dasar konstitusi yang mengatur peran pemerintah dan hubungan antar komunitas agama dan etnik yang hidup bersama dalam suatu pemerintahan. Dokumen konstitusi ini (piagam Madinah) merupakan catatan konstitusi pertama di dunia. Dalam konteks keuangan publik, Piagam Madinah mengatur dua tipe public expenditure, yaitu untuk pertahanan dan tujuan militer, dan untuk tujuan kesejahteraan.

Untuk pengeluaran di bidang militer, Piagam ini menetapkan bahwa komunitas Muslim menyediakan pasukan sendiri dan perlengkapannya dalam mempertahankan negara, sedangkan komunitas Yahudi juga mengadakan pasukan dan perlengkapannya sendiri secara kolektif dalam mempertahankan negara. Adapun tujuan

\footnotetext{
${ }^{23}$ Sumber informasi cukup penting dan klasik dari kalangan orientalis terkait dengan kajian awal keuangan publik pada masa Nabi, lihat uraian Property amongst the Semites (the Arabs) pada $\mathrm{CH}$. Letourneau, Property: Its Origin and Development (London: Walter Scott, Ltd., 1892), 201-206.
}

kesejahteraan disebutkan dalam dokumen konstitusi ini berupa bantuan yang diberikan bagi mereka yang terbebani hutang dan membebaskan tawanan. Dua kebutuhan ini disediakan untuk membangun komunitas etnik kecil di lingkungannya dengan sumber-sumber yang cukup untuk memenuhi tanggung jawab ini. ${ }^{24}$ Dengan demikian, Piagam Madinah ini mampu mengantisipasi pembelanjaan publik yang dibutuhkan untuk mengelola masyarakat, namun tanpa membebani mereka dengan bentuk-bentuk pajak.

Dalam mengatur pemerintahan di Madinah, Nabi mulai mengurus aspek finansial kebutuhan masyarakat dan jaminan pendapatan untuk memenuhi kebutuhan mereka. Dalam sejarah tercatat bagaimana pembelanjaan publik tersebut dapat terpenuhi. Saat itu tamu-tamu negara datang dari luar kota dan mereka membutuhkan tempat perlindungan dan makan. Mereka biasanya bertempat di masjid atau memasang tenda dan memberikan biaya secara sukarela. Ibn $\mathrm{Katsir}^{25}$ memberikan laporan bahwa pembelanjaan publik pertama oleh Nabi di Madinah dalam bentuk pembangunan masjid. Nabi mengeluarkan biaya 600 atau 800 dirham untuk membeli tanah. Pemilik tanah memintanya secara sukarela, namun Nabi menolak dan bersikeras membayarnya dari kontribusi sukarela Abu Bakar.

Setelah perang Khaibar, Nabi menyusun rencana kebutuhan publik. ${ }^{26}$ Beliau menyetujui sebagian tanah diberikan sebagai tanah milik umat dan dikelola para petani; atas permintaan mereka ditetapkan pula bagi hasil atas produksinya. Peristiwa ini menjadi catatan awal penerapan kharaj dalam Islam. Kharaj termanifestasi dalam rencana yang dibuat Nabi atas para pengguna tanah yang memang berdiam di

\footnotetext{
${ }^{24}$ Zafir al-Qasimi, Government System in Syariah and History (Beirut: al-Naqqash Pub., 1974), 32-36.

${ }^{25}$ Lihat Ibn Katsir, Sirah an-Nabawi (Beirut: Dar al-Fikr, 1978), II/303.

${ }^{26}$ Ibn Katsir, Sirah an-Nabawi, III/382.
} 
tanah Khaibar, mengelola tanah, dan kemudian memberikan sebagian produksinya kepada pemilik tanah (owner of the land) yang sekarang dimiliki komunitas Muslim.

Kemudian peranan kharaj sebagai pendapatan publik pemerintah semakin dikembangkan selama periode 'Umar bin Khattab, ketika tanah Irak, Syiria, Mesir, dan Persia dikuasai negara pada tahun 11 sampai $22 \mathrm{H}$. Beberapa tanah yang dikuasai melalui peperangan dan para tentara Muslim mengambilalih tanah tersebut berdasarkan ketentuan standar internasional. 'Umar tidak mendistribusikan tanah ini dan kepemilikannya diberikan kepada umat agar menjadi sumber pendapatan (source of revenue) bagi pemerintah. Kharaj semakin meningkat selama periode ini. Karena itu, kharaj hanya berbentuk penyewaan tanah, atau berupa bagi hasil dari pemilik tanah dalam produksinya. Tanah kharaj ini dimiliki oleh seluruh umat dan seseorang hanya dibenarkan untuk mengelolanya dalam bentuk sistem penyewaan. Setelah penguasaan tanah dan menjadikannya hak milik bagi umat, 'Umar mengirim para pengukur tanah untuk menaksir tanah dan membatasi penyewaan berdasarkan jenis produksinya. ${ }^{27}$ Jadi, 'Umar mengatur kharaj (sewa) untuk setiap tanah yang dikuasai.

Dua abad kemudian, Abu Yusuf, ${ }^{28}$ menyatakan kepada Khalifah Harun arRasyid, kemudian Khalifah menetapkan dua metode dalam pengelolaan kharaj ini atau melalui sistem sewa. Seseorang dapat menyewakan tanah sesuai dengan ukurannya, atau menerapkan bagi hasil dalam produksinya. Seseorang dapat menetapkan $20 \%, 30 \%$ atau berapapun yang ditentukan berdasarkan kesepakatan dengan petani dalam memenuhi kehidupan yang layak dan bekerja pada tanah tersebut selama beberapa tahun. Dengan demikian, kharaj merupakan bentuk penyewaan tanah yang dimiliki umat atau negara yang

\footnotetext{
${ }^{27}$ Abu Ubayd, Kitab al-Amwal, 69.

${ }^{28} \mathrm{Abu}$ Yusuf, Kitab al-Kharaj, 20.
}

merepresentasikan umat. Sejak periode Nabi dan periode berikutnya, kharaj tidak diberlakukan untuk tanah yang tidak dikuasai melalui peperangan. Sebagai contoh, tanah Mekkah dan Madinah, tidak ditetapkan kharaj yang dibebankan kepada masyarakat. Untuk berbagai kebutuhan, kharaj tidak pula diberlakukan pada beberapa kantong wilayah yang berubah menjadi Islam. Sumber klasik seperti Abu 'Ubayd dan Ibn Zanjawayh dalam karyanya yang berlabel sama, al-Amwal, memberikan informasi terkait beberapa tanah di beberapa wilayah yang tidak dikenai kharaj, seperti tanah di antara sungai-sungai dan gununggunung, karena memang penduduknya memeluk Islam sebelum wilayah tersebut dibuka.

Ada beberapa indikator yang menunjukkan praktek public expenditure pada periode ini, seperti pendapatan dari tamu negara dari luar wilayah, dukungan terhadap fakir-miskin, biaya pembayaran hutang bagi orang yang tidak mampu membayarnya, membangun masjid, pengembangan masjid Nabi di Madinah, perluasan beberapa wilayah dan ekspansi masjid di Mekkah sekitar Ka'bah. Setelah Mekkah dibuka dan dikuasai pada tahun ke8 hijrah, tidak ditemukan catatan tentang gaji atau upah para pekerja, termasuk juga catatan tentang para pekerja yang dibayar oleh negara. Ada beberapa orang yang bekerja pada pemerintah tapi atas dasar sukarela. 'Abdullah Ibn Sa'id Ibn al-'Ash, seorang guru dari komunitas Muhajirin, yang mengajar anak-anak sepanjang waktu tapi ia tidak memperoleh pendapatan dari pemerintah. $^{29} \quad$ Catatan lain ${ }^{30}$ menginformasikan pemerintah memberikan

${ }^{29}$ Ibn Atsir, Usd al-Ghabah (Cairo: alSa'bed., 1970), III/262. Lihat juga Aan Jaelani, Keuangan Publik Islam: Refleksi APBN dan Politik Anggaran di Indonesia (Cirebon: Nurjati Press, 2014), dan Aan Jaelani, Keuangan Publik: Analisis Sejarah Pemikiran Ekonomi Islam (Cirebon: CV. Aksarasatu, 2018).

${ }^{30} \mathrm{Ibn}$ Atsir, Usd al-Ghabah (Cairo: alSa'bed., 1970), III/262. 
gaji pada beberapa orang, namun tidak ada informasi pula yang menunjukkan bahwa pemerintah menggaji para tentara saat Mekkah dikuasai. Nabi Saw. menunjuk Gubernur Mekkah, 'Attab bin Usayd, dan memberinya gaji. Ini boleh jadi bentuk penggajian pertama oleh pemerintah dalam Islam.

Meskipun demikian, pada saat pemerintahan berkembang dan semakin luas, Abu Bakar menetapkan gaji. Pada saat menjadi Khalifah, sistem penggajian ditetapkan, begitu juga pada masa Khalifah 'Umar. Pada masa 'Umar, ada daftar gaji pekerja yang diadministrasikan cukup panjang. Para hakim, petugas keamanan, penjaga/polisi malam, para penaksir dan pengoleksi kharaj, dan para gubernur di beberapa wilayah; semuanya memperoleh gaji pada periode 'Umar. Administrasi publik (public administration) dibuat baru dan item besar tentang pembelanjaan, bahkan gaji full time para tentara ditetapkan pula oleh 'Umar. Sebelumnya, para tentara tidak memperoleh gaji untuk pekerjaan full time.

Di samping itu, ada pula item-item lain yang berhubungan dengan administrasi publik dan biaya kesejahteraan (welfare expenses). Sebagai contoh, 'Umar mengembangkan biaya kesejahteraan untuk laki-laki, perempuan, anak-anak, membeli sebuah rumah di Mekkah dan diubah menjadi tempat penjara, menetapkan orang untuk melakukan perawatan atas tanah di luar wilayah yang telah dikuasai, menyediakan tanah untuk tempat penggembalaan bagi ternak yang dizakati, mengangkat para penjaga tanah, dan membentuk para kurir antara Madinah dan kota-kota besar di seluruh propinsi.

Beberapa kebijakan dalam hal pengelolaan keuangan publik mengalami perubahan pada masa 'Utsman ibn 'Affan. Dalam rangka pengembangan sumber daya alam, ia melakukan pembuatan saluran air, pembangunan jalan, dan pembentukan organisasi kepolisian secara permanen untuk mengamankan jalur perdagangan. Di samping itu, ia juga membentuk armada laut hingga berhasil membangun supremasi kelautannya. Dalam hal ini, pemerintahan harus menanggung beban anggaran yang tidak sedikit untuk memelihara angkatan laut tersebut. ${ }^{31}$ Khalifah Utsman ibn 'Affan tetap mempertahankan sistem pemberian bantuan dan santunan serta memberikan sejumlah besar uang kepada masyarakat yang berbeda-beda. Meskipun meyakini prinsip persamaan dalam memenuhi kebutuhan pokok masyarakat, ia memberikan bantuan yang berbeda pada tingkat yang lebih tinggi.

Informasi yang dikemukakan Ibn Jawzi, $^{32}$ menyebutkan bahwa untuk meningkatkan pengeluaran di bidang pertahanan dan kelautan, meningkatkan dana pensiun, dan pembangunan berbagai wilayah taklukan baru, negara membutuhkan dana tambahan. Oleh karena itu, Khalifah Utsman ibn 'Affan membuat beberapa perubahan administrasi tingkat atas dan pergantian beberapa gubernur. Ia juga menerapkan kebijakan membagibagikan tanah negara kepada individuindividu untuk reklamasi dan kontribusi kepada Baitul Mal. Dari hasil kebijakannya ini, negara memperoleh pendapatan sebesar 50 juta dirham atau naik 41 juta dirham jika dibandingkan pada masa 'Umar yang tidak membagi-bagikan tanah tersebut.

Dalam pendistribusian harta baitul mal, Khalifah 'Ali ibn Abi Thalib menerapkan prinsip pemerataan. Ia memberikan santunan yang sama kepada setiap orang tanpa memandang status sosial atau kedudukannya di dalam Islam. 'Ali tetap berpendapat bahwa seluruh pendapatan negara yang disimpan dalam Baitul Mal harus didistribusikan kepada

\footnotetext{
${ }^{31}$ Monzer Kahf (Ed.), Lessons in Islamic Economic, 456.

${ }^{32}$ Abdurrahman Ibn al-Jawzi, Sirah wa Manaqib 'Umar Ibn 'Abdul Aziz al-Khalifah alZahid, (Beirut: Dar al-Kutub al-'Ilmiyah, 1984/1404), 87.
} 
kaum muslimin, tanpa ada sedikitpun dana yang tersisa. ${ }^{33}$

Adapun indikator-indikator praktek public revenues pada periode ini antara lain selama kehidupan Nabi SAW. sumbersumber pendapatan diperoleh dari kontribusi masyarakat secara sukarela (voluntary contribution of people). Bentuk pendapatan ini merepresentasikan sumber utama pada masa awal pemerintahan Islam di Madinah, di mana Nabi mengumpulkan seluruh kontribusi tersebut untuk kebutuhan pembelanjaan publik (public spending). Selain kontribusi sukarela, sumber pendapatan penting lain berupa harta rampasan perang (war booties, ghanimah) yang diperoleh dari perang Badar. Seluruh pendapatan yang ada ditentukan dengan segera sejak diperoleh, terutama untuk distribusi secara langsung bagi para tentara. $^{34}$

Di samping itu, sumber pendapatan berasal dari kepemilikan publik (public property) yang diperoleh sebagai hasil dari orang-orang Yahudi dan telah berkembang sebelumnya ketika tanah Khaibar dikuasai. Pendapatan lain yang cukup besar diperoleh dari pengeluaran zakat. Zakat menjadi kewajiban Muslim yang ditetapkan pada tahun kedua hijrah dan zakat menjadi kategori pendapatan khusus untuk kesejahteraan masyarakat. ${ }^{35}$

Ketika 'Umar menjabat Khalifah, public revenues diklasifikasikan menjadi empat kategori, yaitu: pertama, pendapatan zakat dan 'ushr (pajak tanah). Pendapatan ini didistribusikan dalam tingkat lokal jika kelebihan penerimaan sudah disimpan di Baitul Mal Pusat dan di bagikan kepada delapan ashnaf; kedua, pendapatan khums dan sedekah. Pendapatan ini didistribusikan

\footnotetext{
${ }^{33}$ Abdurrahman Ibn al-Jawzi, Sirah wa Manaqib 'Umar Ibn 'Abdul Aziz, 87-88.

${ }^{34}$ Ibn Zanjawayh, Kitab al-Amwal, (Riyadh: King Faisal Center for Islamic Research and Studies, 1986), II/710-711. Lihat juga Abu Ubayd, Kitab alAmwal, 306.

${ }^{35}$ Abdurrahman Ibn al-Jawzi, Sirah wa Manaqib 'Umar Ibn' Abdul Aziz, 89.
}

kepada para fakir miskin atau untuk membiayai mereka yang sedang mencari kesejahteraan, tanpa diskriminasi apakah ia seorang muslim atau bukan; ketiga, pendapatan kharaj, fay, jizyah, 'ushr (pajak perdagangan), dan sewa tanah. Pendapatan ini digunakan untuk membayar dana pensiun dan dana bantuan serta untuk menutupi biaya operasional administrasi, kebutuhan militer, dan sebagainya; dan keempat, pendapatan lain-lain. Pendapatan ini digunakan untuk membayar para pekerja, pemeliharaan anak-anak terlantar, dan dana sosial lainnya. ${ }^{36}$

Dalam hal pengelolaan zakat, Khalifah Utsman mendelegasikan kewenangan menaksir harta yang dizakati kepada para pemiliknya masing-masing. Hal ini dilakukan untuk mengamankan zakat dari berbagai gangguan dan masalah dalam pemeriksaan kekayaan yang tidak jelas oleh beberapa oknum pengumpul zakat.

Informasi dari Ibn al-Jawzi ${ }^{37}$ menjelaskan bahwa praktek keuangan publik pada masa Umayyah semakin berkembang dan berubah seiring dengan sistem pemerintahan yang berbeda dari sebelumnya dan semakin luasnya wilayah kekuasaan Islam. Dalam hal ini, praktek keuangan publik akan lebih difokuskan pada masa 'Umar ibn 'Abdul Aziz. Kebijakan politik dalam bidang ekonomi menekankan pada pentingnya pembangunan dalam negeri seiring dengan upaya perlindungan dan peningkatan kesejahteraan masyarakat. Ia mengurangi beban pajak yang dipungut dari kaum Nasrani, menghapus pajak dari kaum muslimin, membuat aturan takaran dan timbangan, membasmi cukai dan kerja paksa, dan sebagainya.

Public expenditure digunakan untuk memperbaiki tanah pertanian, penggalian sumur-sumur, pembangunan Jalan-jalan,

\footnotetext{
${ }^{36}$ Ibn Zanjawayh, Kitab al-Amwal, 307.

${ }^{37}$ Kebijakan ekonomi 'Umar bin 'Abdul Aziz secara lengkap dapat dibaca pada bagian Iqtishaduh fi Mal al-'Ummah dalam karya Abdurrahman Ibn al-Jawzi, Sirah wa Manaqib 'Umar Ibn' Abdul Aziz, 88-89.
} 
pembuatan tempat-tempat penginapan para musafir, dan menyantuni fakir miskin. Berbagai kebijakan ini berhasil meningkatkan taraf hidup masyarakat secara keseluruhan hingga tidak ada lagi yang mau menerima zakat. Di samping itu, untuk menegakkan keadilan pada masyarakat, ia membelanjakan kekayaan baitul mal di Irak untuk membayar ganti rugi kepada orangorang yang diperlakukan semena-mena oleh para penguasa sebelumnya. Karena tidak mencukupi, ia mengambil dari kekayaan baitul mal di Syam. ${ }^{38}$

Dalam meningkatkan kinerja pemerintahan, 'Umar Ibn 'Abdul Aziz juga menetapkan gaji pejabat sebesar 300 dinar dan dilarang melakukan pekerjaan sampingan. Selain itu, pajak yang digunakan kepada non-muslim hanya berlaku pada tiga profesi, yaitu pedagang, petani, dan tuan tanah. $^{39}$

Pengeluaran negara dialokasikan pula untuk jaminan sosial bagi mereka yang telah meningggal dunia melalui ahli waris dan para tahanan baik Muslim maupun nonMuslim, serta mendirikan rumah makan khusus untuk para fakir miskin. Jika pendapatan negara memiliki nilai surplus setelah digunakan untuk memenuhi kebutuhan kaum muslimin, maka didistribusikan kepada ahl al-dzimmi, bahkan diberikan pinjaman tanah-tanah pertanian sebagai lahan pekerjaan mereka.

Public revenues diperoleh dari berbagai sumber-sumber ekonomi dengan menerapkan prinsip keadilan seperti zakat, ghanimah, pajak penghasilan pertanian, dan hasil pemberian lapangan kerja produktif kepada masyarakat luas. Dalam bidang pertanian, misalnya, prinsip efisiensi dilakukan dengan melarang penjualan tanah garapan agar tidak ada penguasaan lahan, di samping pemanfaatan lahan pertanian yang ada. Pendapatan dari hasil sewa tanah

\footnotetext{
${ }^{38}$ Monzer Kahf (Ed.), Lessons in Islamic Economic, 457-458.

${ }^{39}$ Abdurrahman Ibn al-Jawzi, Sirah wa Manaqib 'Umar Ibn 'Abdul Aziz, 90-91.
}

mempertimbangkan tingkat kesuburan tanah dan kesejahteraan hidup petani.

Berdasarkan uraian di atas, ada beberapa karakteristik umum pada public expenditure dan public revenues pada periode Nabi, Khulafa' al-Rasyidin, dan Umayyah antara lain adanya pembentukan modal sosial atau modal publik, seperti modal yang ditetapkan negara tapi tidak digunakan atau dikembangkan tersendiri melainkan menjadi sumber pendapatan publik. Secara jelas, tanah menjadi sumber pendapatan utama yang menghasilkan modal, sehingga tanah ini ditetapkan pemerintah sebagai sumber pendapatan yang dikumpulkan pada baitul mal (the treasury).

Karakteristik lain berupa pinjaman publik (public borrowing) yang dimulai pada masa Nabi. Nabi sendiri melakukan pinjaman kepada 'Umar dan beberapa sahabat, juga pernah meminjam senjata kepada non-Muslim. Nabi melakukan pinjaman publik, tapi tidak membebankan pajak. Untuk maksud pajak, Nabi menggunakan istilah lain berupa "zakat". Dalam hal ini, Nabi pernah meminta pamannya, 'Abbas, untuk membayarkan zakat selama dua tahun sekaligus. ${ }^{40}$

Kemudian pada masa 'Umar, pemerintah menunda pengumpulan zakat ketika terjadi kelaparan di Madinah dan daerah sekitarnya, dan pada tahun berikutnya zakat dikumpulkan dua kali sekaligus. ${ }^{41}$ Hal ini bermakna, zakat sebagai instrumen kebijakan fiskal bersifat fleksibel untuk ditunda atau dipercepat pelaksanaannya melebihi satu tahun, di samping bermakna redistribusi kesejahteraan dan suatu alternatif atas nasionalisasi.

Di samping itu, ciri berikutnya berupa adanya kebergantungan atas inisiatif swasta ketika pengolahan tanah dikuasai oleh pemerintah. Penguasaan tanah Khaybar

\footnotetext{
${ }^{40}$ Abu Ubayd, Kitab al-Amwal, 589.

${ }^{41}$ Abu Ubayd, Kitab al-Amwal, 374 dan 592. Lihat pula Ibn Zanjawayh, Kitab al-Amwal, II/830.
} 
merupakan seluruh pemberian yang digunakan pihak swasta dalam mengolah pertanian. Distibusi tanah oleh Nabi digunakan untuk tujuan pertanian atau peternakan. Nabi menekankan pula kepada para sahabat untuk aktif dalam perdagangan, keahlian, dan aktivitas produktif lainnya. Hal ini menunjukkan bahwa filsafat ekonomi negara berdasarkan atas peningkatan peran swasta dan menganggapnya sumber ekonomi utama yang mensejahterakan individu dan masyarakat secara keseluruhan. ${ }^{42}$ Di samping itu, Nabi mengatur pula tempattempat yang menjadi kepemilikan publik (public property) dalam rangka memenuhi kebutuhan publik (public needs), misalnya menetapkan tanah penggembalaan umum bagi kuda-kuda yang dimiliki orang Muslim.

Pada masa ini ditandai pula dengan penguatan peran negara untuk memajukan dan mendorong sektor privat. Filosofi produksi atas kepercayaan diri semakin berkembang. Dalam hal ini, zakat sebagai bentuk ibadah finansial ('ibadat bi al-mal) dapat dipraktekkan oleh muzakki yang mampu membayarnya. Nabi mengingatkan bahwa tangan di atas lebih baik dan disukai Allah daripada tangan di bawah. ${ }^{43}$

Ciri berikutnya dalam bentuk penekanan pada prinsip kontribusi keuangan secara sukarela bagi aktivitas-aktivitas negara. Dalam pandangan Monzer Kahf, ${ }^{44}$ prinsip ini disebut kontribusi sukarela pada prinsip demokratisasi pemerintah yang dihadapkan dengan prinsip kedaulatan pemerintah yang membebankan retribusi pajak. Hal ini dinamakan pula dengan demokratisasi pembelanjaan publik.

\footnotetext{
${ }^{42}$ Al-Mawardi, al-Ahkam as-Sulthaniyah wa-al-Wilayat ad-Diniyah, h. 185. Menurut Abu Ubayd, tanah ini digunakan untuk kuda-kuda yang dipakai dalam peperangan. Abu Ubayd, Kitab alAmwal, 185.

${ }^{43}$ Al-Mawardi, al-Ahkam as-Sulthaniyah wa-al-Wilayat ad-Diniyah, 186.

${ }^{44}$ Monzer Kahf (Ed.), Lessons in Islamic Economic, 460.
}

Adapun pada aspek pendapatan publik dijadikan mata rantai pembelanjaan publik. Ada beberapa bentuk public revenues yang memiliki kegunaan spesifik, misalnya pemerintah memanfaatkan pendapatan publik ini hanya untuk belanja negara. Sebagai contoh, zakat sebagai pendapatan publik hanya dimanfaatkan untuk delapan kategori pembelanjaan (mustahiq zakat) yang ditetapkan al-Qur'an (Q.S. 9:60). Begitu juga dengan fay' sebagai harta rampasan dari musuh tanpa peperangan yang distribusinya terbatas untuk lima kategori yang diatur dalam alQur'an (Q.S. 59:7). Kontribusi sukarela yang dikumpulkan tersebut digunakan untuk proyek-proyek umum atau aktivitas yang digunakan untuk tujuan tertentu sebagaimana yang telah dipraktekkan oleh Nabi.

Pada tahap selanjutnya, pengumpulan pajak dilakukan bila tidak mencukupi pendapatan, dan pemerintah dapat membuat kebijakan atas penerapan pajak baru yang dibutuhkan bagi keberlangsungan belanja pemerintah. Ini yang dinamakan pendapatan memiliki mata rantai dengan pembelanjaan. Mata rantai ini tidak mengutamakan keseimbangan pemasukan akibat adanya pinjaman publik (public borrowing) yang menunjukkan bahwa pemasukan dan pengeluaran tidak seimbang. Karena itu, pada masa 'Umar, ada surplus keuangan pada baitul mal yang digunakan untuk tahun berikutnya. Juga, penangguhan pengumpulan zakat atau pengumpulan zakat yang dipercepat pada saat ada ketidakseimbangan dalam keuangan. $^{45}$

\section{Politik Keuangan dan Sistem Kesejahteraan Masyarakat}

Seiring dengan perkembangan wilayah, otonomi keuangan diterapkan oleh pemerintah pada propinsi-propinsi di berbagai wilayah negara Islam. Misalnya,

\footnotetext{
${ }^{45}$ Al-Mawardi, al-Ahkam as-Sulthaniyah wa-al-Wilayat ad-Diniyah, 186-187.
} 
zakat bersifat lokal yang dikumpulkan setiap propinsi atau segmen yang lebih kecil dan pendistribusiannya dilakukan di wilayah tersebut. Menurut Abu 'Ubayd, ${ }^{46}$ hal ini didukung oleh kebijakan 'Umar yang menetapkan bagian pemerintah pusat atas zakat yang diperoleh propinsi Yaman, dengan Mu'az sebagai gubernurnya. Penjelasan Mu'az menunjukkan bahwa ia tidak mendistribusikan zakat secara lokal seluruhnya, karena ia tidak menemukan sejumlah orang yang membutuhkan untuk menerima zakat, dan ia kemudian memperoleh surplus zakat di propinsi tersebut. Bahkan, pemerintah propinsi merupakan penentu kebijakan final dengan menetapkan penanggungjawab pembelanjaan di tiap-tiap propinsi sekaligus sebagai pusat kontrol, inspeksi, dan penanggungjawab seperti yang dipraktekkan pada masa 'Umar.

Pemerintah pusat di Madinah memperoleh pemasukan kecil, kecuali zakat dan ' $u s h r$ yang memiliki kategori penerima tersendiri, pemerintah pusat tidak memiliki sumber-sumber pendapatan. Pemerintah pusat bergantung pada surplus kharaj yang telah dimanfaatkan dari propinsi-propinsi sebelah Utara Syiria, Irak, Persia, dan Mesir yang sebagian besar tanahnya berupa tanah kharaj. Sedangkan pada masa 'Umar diperkenalkan peran pemerintah terkait hubungan perdagangan internasional. Ia menginformasikan kepada para gubernur terkait dengan beberapa tamu asing di propinsi, bahwa negara lain memberlakukan biaya bagi pedagang Muslim yang memasuki wilayahnya dengan pajak sebesar $10 \%$ dari nilai barang yang diperdagangkan. Setelah berkonsultasi dengan sahabat lain dan para gubernur propinsi, 'Umar menetapkan bahwa pemerintah Islam juga menetapkan biaya bagi pedagang yang memasuki wilayahnya

${ }^{46}$ Abu Ubayd, Kitab al-Amwal, 596. Baca juga Aan Jaelani, Manajemen Zakat di Indonesia dan Brunei Darussalam (Cirebon: Nurjati Press, 2015). dengan pajak sebagai basis resiprositas. ${ }^{47}$ Untuk penerapan pajak ini kepada para pedagang luar negeri, 'Umar mengangkat kolektor pajak dan menempatkannya di pinggiran wilayah, daerah perbatasan, dan Jalan-jalan utama yang menghubungkan wilayah Muslim dengan wilayah sekitarnya. Meskipun demikian, seperti dikemukakan Abu Yusuf, ${ }^{48}$ pada penerapan prinsip resiprositas ini dalam keuangan publik, 'Umar mencatat bahwa beberapa produk domestik dibutuhkan dan dipesan para pedagang luar negeri untuk keperluan makanan, kemudian ia menetapkan pajak import sebesar $5 \%$.

Periode ini ditandai pula dengan kebijakan tentang kekayaan dan aset publik (public funds and assets) yang perlu dijaga dan mengandung nilai religius. Al-Qur'an menjelaskan tentang proteksi dana publik dari pencurian dan penyalahgunaannya. ${ }^{49}$ Informasi dari Ibn Kathir ${ }^{50}$ menyebutkan bahwa pada periode Nabi, beberapa orang diangkat menjadi bendahara publik, di antaranya Bilal. Ia menyimpan harta pendapatan negara pada tempat penyimpanan dan mendistribusikannya sesuai perintah dari Nabi. Kadang-kadang hasil pendapatan publik disimpan di rumah Nabi. Sejak masa Abu Bakar, ada tempat khusus untuk penyimpanan pemasukan negara, namun sejak masa 'Umar dibentuk departemen khusus "baitul mal" dan ia mengangkat pegawai untuk mengelola baitul mal. Peningkatan kesejahteraan masyarakat dilakukan dengan mengurangi seluruh beban ekonomi yang harus ditanggung oleh masyarakat. Sebaliknya, pemerintah membuat kebijakan belanja negara untuk memberikan jaminan sosial dan menghapuskan beberapa sumber pendapatan negara seperti pajak dan bea masuk.

\footnotetext{
${ }^{47}$ Abu Yusuf, Kitab al-Kharaj, 134.

${ }^{48} \mathrm{Abu}$ Yusuf, Kitab al-Kharaj, 135.

${ }^{49}$ QS. Al-Maidah (3): 161.

${ }^{50}$ Ibn Katsir, Sirah an-Nabawi, III/286.
} 
Adapun praktek pengelolaan anggaran pada masa Abbasiyah mengalami kemajuan dengan adanya konsolidasi dan penertiban administrasi birokrasi, seperti mengangkat seorang wazir sebagai koordinator departemen, membentuk lembaga protokol negara, sekretaris negara, dan kepolisian negara, serta membenahi angkatan bersenjata dan membentuk lembaga kehakiman negara. Peranan jawatan pos semakin ditingkatkan dengan tambahan tugas menghimpun seluruh informasi di berbagai daerah, sehingga administrasi negara dapat berjalan dengan lancar dan melaporkan perilaku gubernur setempat kepada Khalifah.

Pemerintahan

Abbasiyah menerapkan kebijakan politik ekonomi dalam rangka meningkatkan kesejahteraan masyarakat. Public revenues bersumber dari sektor pertanian yang sebelumnya dibuat kebijakan dalam meningkatkan irigasi, sektor pertambangan, seperti emas, perak, tembaga, dan besi, dan sektor perdagangan dengan membuka jalur transit perdagangan antara timur dan barat yang banyak menghasilkan kekayaan yang menjadikan Bashrah sebagai pelabuhan yang penting. ${ }^{51}$

Publik expenditure diterapkan berdasarkan politik ekonomi pemerintah dalam upaya meningkatkan sektor pertanian dengan membuat kebijakan yang membela hak-hak kaum tani, seperti peringanan beban pajak hasil bumi, penjaminan hak milik dan keselamatan jiwa, perluasan lahan pertanian di setiap daerah, dan pembangunan berbagai bendungan dan kanal. Untuk meningkatkan sektor perdagangan, pemerintah membuat sumur-

\footnotetext{
${ }^{51}$ Baca S.M. Ghazanfar, "Public Sector Economics in Medieval Economic Thought: Contributions of Selected Arab-Islamic Scholars" dalam S.M. Ghazanfar (ed.), Mediavel Islamic Economic Thought: Filling the Great Gap in European Economics (London \& New York: Routledge Curzon, 2003), 228-244, dan Aan Jaelani, Sejarah Pemikiran Ekonomi Islam: Kontribusi Sarjana Muslim dalam Pemikiran dan Analisis Ekonomi (Cirebon: CV. Aksarasatu, 2018).
}

sumur, membangun tempat-tempat peristirahatan para kafilah dagang, dan mendirikan berbagai armada dagang, serta menjaga keamanan pelabuhan dan pantai.

Secara khusus, pada masa Harun arRasyid (170-193 H.), pertumbuhan ekonomi berkembang dengan pesat dan kemakmuran negara mencapai puncaknya. Sumbersumber public revenue diverifikasi dan menata ulang pengelolaan baitul mal. Pendapatan publik diperoleh dari kharaj, jizyah, zakah, fay', ghanimah, 'ushr, dan harta lainnya, seperti wakaf, sedekah, dan harta warisan orang yang tidak mempunyai ahli waris. Adapun public expenditure digunakan berdasarkan kebutuhan, antara lain untuk riset ilmiah dan penerjemahan buku-buku Yunani, biaya pertahanan dan anggaran rutin pegawai, membiayai para tahanan dalam penyediaan bahan makanan dan pakaian.

Catatan penting pada masa ini adalah perintah Harun ar-Rasyid kepada Abu Yusuf untuk menulis tentang masalah perpajakan, al-kharaj, sebagai pedoman pemerintah. ${ }^{52}$ Kitab ini menjadi pedoman dalam pengelolaan keuangan publik berdasarkan syari'ah. Misalnya, pemungutan kharaj dapat dilakukan melalui tiga metode, yaitu al-muhasabah atau penaksiran luas areal tanah dan jumlah pajak yang harus di bayar dalam bentuk uang; al-muqasamah atau penetapan jumlah tertentu (persentase) dari hasil yang diperoleh; dan al-muqatha'ah atau penetapan pajak hasil bumi terhadap para aghniya' berdasarkan persetujuan antara pemerintah dengan yang bersangkutan.

Public revenues bersumber dari kharaj, jizyah, zakat, fay', ghanimah, dan 'ushr. Sistem desentralisasi diterapkan dalam mengatur pemungutan pajak. ${ }^{53}$

${ }^{52}$ Baca pengantar Abu Yusuf pada karyanya, Kitab al-Kharaj, 1-3. Bandingkan dengan karya Muh. Dia'u al-Din Al-Rayyis, al-Kharaj and the Financial Institutions of the Islamic Empire (Cairo: the Anglo Egyptian Library, 1961).

${ }^{53}$ Baca Metin M. Cosgel,"Efficiency and Continuity in Public Finance: The Ottoman System 
Namun, kemudian diubah secara sentralistik akibat kurangnya kontrol pemerintah pusat akibat perang dengan Eropa dan wilayah yang luas, dan adanya penyimpangan dari para pejabat lokal, seperti memungut pajak melebihi batas kewajiban, memanipulasi pengutipan pajak, membebani kewajiban tambahan kepada para petani, serta melegitimasi berbagai praktek pungutan liar.

Pendapatan publik diperoleh pula dari pertanian yang diklasifikasikan menjadi dua jenis tanah garapan, al-iqtha' alashghar atau timar dan ziamat timar sebagai tanah garapan terkecil yang diberikan pemilik tanah kepada para petani untuk diolah. Hasil timar ini diserahkan sepenuhnya kepada pemilik tanah, sedangkan petani mendapat bagian yang hanya mampu memenuhi keperluan makan sehari-hari. Setiap pemilik timar berkewajiban menyerahkan dua sampai empat ekor kuda atau beberapa orang calon tentara angkatan laut kepada pemerintah, di samping membayar pajak kekayaan. Untuk menunjang pelaksanaan kewajiban ini, pemerintah menetapkan seorang pengawas pada setiap timar. Adapun ziamat merupakan tanah garapan yang diberikan pemerintah kepada para petani untuk diolah. Pemilik tanah atau za'im mempunyai kewajiban membayar pajak dan mengirimkan sejumlah calon tentara sesuai dengan luas ziamat yang dimiliki.

Public expenditure diterapkan dengan prinsip efisiensi, seperti untuk gaji pasukan jenissari dan keperluan istana. Belanja negara dipakai pula untuk pembangunan masjid dan istana yang megah, sekolah, rumah sakit, panti asuhan, penginapan, pemandian umum, dan pusatpusat tarekat.

\section{Analisis tentang Pasar Bebas dan Keadilan Ekonomi}

Pemikiran ekonomi yang menganut pasarbebas, efisiensi tak lain merupakan suatu

of Taxation", dalam The Economic of Ottaman Taxation, University of Connecticut (2004), 329-331. "keterpaksaan ekonomi" untuk bertahan hidup dan meraih keuntungan ekonomi (lebih berdasar zero-sum daripada non-zerosum), yang harus dicapai melalui bersaing. Sedang di dalam pemikiran ekonomi yang mengakui kerjasama mutualitas sebagai kekuatan ekonorni, maka efisiensi merupakan "kewajiban hidup berekonomi". Ekonomi persaingan berjangkauan kepentingan parsial (nilai-tambah ekonomi), sedang ekonomi kerjasama berjangkauan kepentingan multi-parsial yang lebih lengkap dan menyeluruh (mencakup nilaitambah ekonomi dan nilai-tambah sosialkultural sekaligus).

Efisiensi ekonomi dapat dianalisis dalam pandangan Ibn Khaldun. Menurut Ibnu Khaldun, ${ }^{54}$ mekanisme penawaran dan permintaan akan menentukan harga keseimbangan. Pada sisi permintaan, persaingan diantara konsumen untuk mendapatkan barang memiliki pengaruh, begitu juga, pada sisi penawaran akan berpengaruh pada meningkatnya biaya produksi karena pajak dan pungutanpungutan lain di suatu kota. Dalam konteks penawaran dan permintaan, ketika barangbarang yang tersedia sedikit, maka hargaharga akan naik. Namun, bila jarak antara kota dekat dan amam, maka akan banyak barang yang diimpor sehingga ketersediaan barang akan melimpah dan harga-harga akan turun. Pada sisi lain, keuntungan yang wajar akan mendorong tumbuhnya perdagangan, sedangkan keuntungan yang sangat rendah, akan membuat lesu perdagangan, karena pedagang kehilangan motivasi. Sebaliknya bila pedagang mengambil keuntungan sangat tinggi, juga akan membuat lesu perdagangan, karena lemahnya permintaan konsumen.

Dalam pandangan Ibnu Taimiyah, pemerintah bertanggung jawab untuk menyediakan kebutuhan dasar seperti makanan, tempat tinggal, kesehatan dan pendidikan kepada warga negaranya. Selain

${ }^{54}$ Ibn Khaldun, The Muqaddimah (Cairo: Dar Ibn al-Haitham, 2005), II/271-278. 
itu, Ibnu Taimiyah adalah mendukung intervensi negara untuk menghilangkan kegiatan usaha riba, kemiskinan, dan kerusakan dalam perekonomian. ${ }^{55}$

Dalam hal ini, seorang muhtasib sebagai pengawas dan suvervisor pasar dalam menjalankan tugas melalui lembaga hisbah harus mampu menciptakan efisiensi pasar. ${ }^{56}$ Efisiensi pasar dapat terwujud bila mekanisme pasar berjalan tidak sempurna, yang disebabkan oleh: (1) kekuatan pasar yang dapat menentukan harga dan kuantitas keseimbangan; (2) eksternalitas, yaitu aktivitas konsumsi/produksi yang mempengaruhi pihak lain, tidak tercermin di pasar; (3) adanya barang publik; dan informasi tidak sempurna yang menyebabkan inefisiensi dalam permintaan dan penawaran.

Dengan demikian, peran pemerintah memiliki arti penting dalam mengatur mekanisme pasar dan menolak pasar bebas yang jelas merugikan rakyat. Bagaimanapun juga secara syari'ah, pemerintah berperan dalam pemenuhan kebutuhan dan pelayanan sosial bagi masyarakat. Mengutip Sri- Edi Swasono, negara harus turut campur tangan dan tidak menitipkan nasib rakyat dan kepentingan negara kepada selera dan kehendak pasar bebas. Tidak hanya itu, negara diharapkan mampu mendesain dan menata perekonomian agar terwujud kesejahteraan dan keadilan sosial di tengah masyarakat. Jadi, kebersamaan dan kerja sama menjadi kunci jawaban karena bagaimanapun demokrasi ekonomi yang mementingkan masyarakat (public-interest atau social-interest) lebih utama dibanding kepentingan orang-perorang (self-interest).

Ekonomi Islam tetap konsisten memotong segala tindakan dan rekayasa yang membuat harga naik-turun tidak alami lagi. Karena itu, Islam melarang ihtikar (penumpukkan barang, agar langka dan

\footnotetext{
${ }^{55}$ Ibn Taymiyah, al-Hisbah fi al-Islam, 2.

${ }^{56}$ Ibn Taymiyah, al-Hisbah fi al-Islam, 7-17. Lihat juga Abdul Azim Islahi, Economic Concepts of Ibnu Taimiyah, 179-180.
}

harga naik), mengharamkan talaqi rukban (memborong barang dengan harga di bawah standar sebelum sampai di pasar), tala'ub bi ats-tsaman (mempermainkan harga), taghrir (menipu dalam jual-beli), riba, najs (calo, pura-pura menawar untuk menipu pembeli agar membayar dengan harga yang lebih tinggi), tashriyah (tidak memerah susu binatang agar dianggap selalu bersusu banyak), dan sebagainya. Jadi, segala tindakan negatif, baik oleh penjual maupun pembeli yang menimbulkan stabilitas pasar menjadi terganggu dengan naik-turunnya harga yang tidak lagi alami, tidak diperkenankan dalam praktek ekonomi Islam.

Pasar bebas harus dapat dikendalikan agar terjamin kesetimbangan sosial. Kualitas kesetimbangan ini akan mengendalikan semua segi tindakan manusia - sebagai faktor terpenting atas perilaku ekonomi. Hal ini dapat dianalisis; pertama, hubungan dasar antara konsumsi, produksi, dan distribusi akan berhenti pada suatu kesetimbangan tertentu, untuk menghindari pemusatan kekuasaan ekonomi dalam genggaman segelintir orang (monopoli yang eksploitatif); kedua, keadaan perekonomian yang dipengaruhi pola perdagangan bebas harus konsisten dengan distribusi pendapatan dan kekayaan secara merata serta tidak semakin menyempit (QS. 59:7). ${ }^{57}$ Dalam hal ini, Islam melarang pula penimbunan kekayaan (QS. 4:37), sekaligus melarang konsumsi yang melampaui batas dan memuji kebajikan infak (QS. 2:195).

Pembangunan ekonomi sangat penting bagi kesejahteraan. Secara global dan khususnya di negara-negara industri maju, pertumbuhan ekonomi telah memperkuat integrasi dan solidaritas sosial, serta memperluas kemampuan dan akses orang terhadap pelayanan kesehatan, pendidikan, tempat tinggal, dan perlindungan

\footnotetext{
${ }^{57}$ Haider Naqvi, Ethics and Economics: an Islamic Synthesis (London: The Islamic Foundation, 1981), 34-68.
} 
sosial. Namun demikian, analisis Edi Suharto, 58 pada banyak negara berkembang, globalisasi dan ekonomi pasar bebas telah memperlebar kesenjangan, menimbulkan kerusakan lingkungan, menggerus budaya dan bahasa lokal, serta memperparah kemiskinan.

Peran ekonomi rakyat perlu ditempatkan sebagai strategi pembangunan. Makna strategis ekonomi rakyat dalam pembangunan antara lain: (1) rakyat yang secara partisipatori-emansipatori berkesempatan aktif dalam kegiatan ekonomi akan lebih menjamin nilai tambah ekonomi optimal yang mereka hasilkan dapat secara langsung diterima oleh rakyat. Pemerataan akan terjadi seiring dengan pertumbuhan; (2) memberdayakan rakyat merupakan tugas nasional untuk meningkatkan produktivitas rakyat sehingga rakyat secara konkret menjadi aset aktif pembangunan. Subsidi dan proteksi kepada rakyat untuk membangun diri dan kehidupan ekonominya merupakan investasi ekonomi nasional dalam bentuk human investment (bukan pemborosan atau inefficiency) serta mendorong tumbuhnya kelas menengah yang berbasis grass-roots; dan (3) pembangunan ekonomi rakyat meningkatkan daya beli rakyat yang akan menjadi energi rakyat untuk lebih mampu membangun dirinya sendiri (selfempowering).

\section{KESIMPULAN}

Berdasarkan uraian di atas, dapat ditarik kesimpulan bahwa relasi negara dan pasar bebas harus dapat diimplementasikan dalam berbagai kebijakan politik pemerintah dalam mengelola keuangan yang dapat mewujudkan kesejahteraan ekonomi. Dalam sejarahnya, prioritas fungsi masyarakat menjadi indikator pembangunan yang secara

\footnotetext{
${ }^{58}$ Edi Suharto, Membangun Masyarakat Memberdayakan Rakyat: Kajian Strategis Pembangunan Kesejahteraan Sosial dan Pekerjaan Sosial (Bandung: Refika Aditama, 2005), 48.
}

nyata diwujudkan seiring dengan penguatan aspek keagamaan, keadilan, dan bantuan kepada orang miskin, serta implementasi hukum Islam dan nilai-nilai pada berbagai aspek, kemudian diikuti dengan jaminan material kesejahteraan hidup manusia. Adapun perkembangan pasar bebas agar dikendalikan dengan berpegang pada prinsip-prinsip keadilan yang secara khusus menyentuh semangat nasional, etnik, geografis, bentuk dan afiliasi agama, yang secara keseluruhan dipraktekkan untuk mewujudkan kesejahteraan ekonomi.

\section{DAFTAR PUSTAKA}

Al-Syatibi, Abu Ishaq. al-Muwafaqat $f i$ Ushul asy-Syari'ah. Cairo: alMaktabah al-Tijaniyah al-Kubra, 1975, II.

Abu Ubayd. Kitab al-Amwal. Cairo: Maktabah al-Tijariyah al-Kubra, 1934.

Abu Yusuf. Kitab al-Kharaj. Beirut: Dar alMa'arif, 1979.

Ahmed, Ziauddin, etc. Fiscal Policy and Resource Allocation in Islam. Jeddah: King Abdul Aziz University \& Islamabad: Institute of Policy Studies, 1996.

Al-Ghazali. Ihya' 'Ulum ad-Din, Beirut: Dar al-Nadwah, 1995, II.

Al-Mawardi. Abu Hasan Ali, Adab alDunya wa-ad-Din. Beirut: Dar al-Fikr, 1995.

Al-Mawardi, Abu Hasan Ali, al-Ahkam asSulthaniyah wa-al-Wilayat adDiniyah. Beirut: Dar al-Fikr, 2005.

Al-Rayyis, Muh. Dia'u al-Din. Al-Kharaj and the Financial Institutions of the Islamic Empire. Cairo: the Anglo Egyptian Library, 1961.

Azmi, Sabahuddin. Islamic Economics: Public Finance in Early Islamic Thought. New Delhi: Goodword Books, 2002.

Chapra, Umar. The Future of Economics: An Islamic Perspective. SEBI: 2001.

Cosgel, Metin M.,'Efficiency and Continuity in Public Finance: The Ottoman System of Taxation", dalam 
The Economic of Ottaman Taxation, University of Connecticut (2004).

Cosgel, Metin M.,"Efficiency and Continuity in Public Finance: The Ottoman System of Taxation," International Journal of Middle East Studies 37(4) (2005).

Ghazanfar, S.M. (ed.). Medieval Islamic Economic Thought: Filling the Great Gap in European Economics. London \& New York: Routledge Curzon, 2003 .

Ibn al-Jawzi, Abdurrahman. Sirah wa Manaqib 'Umar Ibn 'Abdul Aziz alKhalifah az-Zahid. Beirut: Dar alKutub al-'Ilmiyah, 1984/1404.

Ibn Atsir. Usd al-Ghabah. Cairo: al-Sa'bed, 1970, III.

Ibn Katsir. Sirah al-Nabawi. Beirut: Dar alFikr, 1978, II.

Ibn Taymiyah. al-Hisbah fi al-Islam. Beirut: Dar al-Kutub al-'Arabiyah, 1990.

Ibn Zanjawayh. Kitab al-Amwal. Riyadh: King Faisal Center for Islamic Research and Studies, 1986, II.

Islahi, Abdul Azim. Economic Concepts of Ibnu Taimiyah. United Kingdom: The Islamic Foundation, 1996.

Jaelani, Aan. Fiscal Policy in Indonesia: Analysis of State Budget 2017 in Islamic Economic Perspective. International Journal of Economics and Financial Issues, Vol. 7, No. 5 (2017).

Jaelani, Aan. Keuangan Publik Islam: Refleksi APBN dan Politik Anggaran di Indonesia. Cirebon: Nurjati Press, 2014.

Jaelani, Aan. Keuangan Publik: Analisis Sejarah Pemikiran Ekonomi Islam. Cirebon: CV. Aksarasatu, 2018.

Jaelani, Aan. Manajemen Zakat di Indonesia dan Brunei Darussalam. Cirebon: Nurjati Press, 2015.

Jaelani, Aan. Masyarakat Islam dalam Pandangan al-Mawardi. Bandung: Pustaka Setia, 2006.

Jaelani, Aan. Sejarah Pemikiran Ekonomi Islam: Kontribusi Sarjana Muslim dalam Pemikiran dan Analisis Ekonomi. Cirebon: CV. Aksarasatu, 2018.

Kahf, Monzer, (ed.), Lessons in Islamic Economic, Jeddah: IDB-IRTI, 1998.

Naqvi, Haider. Ethics and Economics: an Islamic Synthesis, London: The Islamic Foundation, 1981.

Suharto, Edi. Membangun Masyarakat Memberdayakan Rakyat: Kajian Strategis Pembangunan Kesejahteraan Sosial dan Pekerjaan Sosial. Bandung: Refika Aditama, 2005.

Swasono, Sri-Edi. Ekspose Ekonomika: Mewaspadai Globalisasi dan Pasar Bebas. Yogyakarta: Pustep-UGM, 2010.

Swasono, Sri-Edi. Indonesia dan Doktrin Kesejahteraan: Dari Klasikal dan Neoklasikal sampai ke The End of Laissez-Faire. Jakarta: Perkumpulan Prakarsa, 2010.

Swasono, Sri-Edi. Kebersamaan dan Asas Kekeluargaan: Mutualism \& Brotherhood. Jakarta: UNJ Press, 2005.

Swasono, Sri-Edi. Kembali ke Pasal 33 UUD 1945 Menolak Neoliberalisme. Jakarta: Yayasan Hatta, 2010.

Haron, Mohamad Sabri Haron. "Wealth Protection in The Context of Maqasid Syariah: Malaysia's Role ini Realizing The Concept of Economic Jihad", Jurnal Hadhari Edisi Khas 2:2 (Desember 2017).

Nazir, Moh. Nazir. Metode Penelitian. Bandung: Ghalia Indonesia, 2003.

Soekanto, Soerjono dan Sri Mamudji. Penelitian Hukum Normatif Suatu Tinjauan Singkat, Cet. 11. Jakarta: PT. Raja Grafindo Persada, 2009.

Sugiyono. Metode Penelitian Kuantitatif Kualitatif Dan $R$ \& D. Bandung: Alfabeta, 2013.

Rahmat, Jalaludin. Metodologi Hukum. Jakarta: Fajar Agung, 1997. 